\title{
報
}

\section{クン蒸剤「酸化エチレン」に関する研究 (第7報)}

\author{
保管穀類に加害する糸状菌の殺菌と種子の発芽について
}

(昭 和 41 年 4 月 22 日 受 理)

鶴 田理 ${ }^{* 1}$ 石原暉子*2

Studies on Fumigant "Ethylene Oxide" (VII)

Strilization of Mould Injurious to the Stored Cereals and Influence on Germination of Plant Seeds

\section{Osamu TSURUTA*1 and Akiko ISHIHARA*2}

(*1 Food Research Institute, Ministry of Agriculture and Forestry: 2, Hamazono-cho, Fukagawa, Koto-ku, Tokyo; ${ }^{2}$ Ekika Tansan Co., Ltd.: 5-20, Shimo, Kita-ku, Tokyo)

The condition of sterilization of mould readily parasitic to the stored cereals was investigated to obtain the highest efficiency of fumigant the effective minimum fumigating times were as follows:

2 hours for the ethylene concentration of $30 \%$ in fumigation chamber, 48 hours for $0.8 \%$ and for the concentration of $0.7 \% 72$ hours to expect a complete effect.

The influence of the fumigant to the seed germination was also observed and it was found that the effect depends on the kind of the subjected plant.

In this respect, in general, shorter fumigating time with higher fumigant concentration is preferable to the opposite way.

(Received April 22, 1966)

\section{緒言}

酸化エチレンあるいは酸化エチレンを主剤とした混合 剂を用いた場合における殺菌, 殺虫効果, あるいはクン 蒸物質に及ぼす影響とその際における浸透の様相等につ いては報告1) 6)を重ねてきている。これらは特定容器内 での使用を前提としたものが多く，一般の保管穀類等を 対象とする倉庫クン蒸の場合とはいささか趣意を異にし ている，そこで本報では，従来のクン蒸ガス置換の方法 に加えて，常態で爆発域を有しない混合薬剤をも，倉庫 クン蒸を想定した条件で用い，保管穀類を加害する主体 の糸状菌への効果と種子の発芽に及ぼす影響について検 討を加えたので，これらより得た幾つかの知見を取りま とめ報告する。

*1 農林省食糧研究所：東京都江東区深川浜園町 2

*2 液化炭酸株式会社: 東京都北区志茂 5-2

\section{A）一般のクン蒸方法によった場合}

酸化エチレンを主剤としたクン蒸剤には，用途によっ て不活性ガスとの混合比を異にしたものが用いられてい る。そこで，種子類の発芽に及ぼす影響あるいは殺菌効 果を検討するに際しての供試薬剤には, 常態で爆発域を 有しない酸化エチレン 10 と炭酸ガス 90 の混合体（カポ ックス10）を用い，一般クン蒸方法によって実験を行な った。

\section{実験方法}

微生物への効果を知る試料としては，保管中に穀類を 変質させる主体は系状菌であり, その中核は Aspergillaceae であるところから，このらちより特徽的な性格 を有する Pen. islandicum と Asp. chevalieri を選択 し，これを玄米に10１4日寄生させたものを用いた。こ れらの供試に際しては，あらかじめ殺菌を施した両端綿 センのガラス管 (径 $1.7 \times$ 長さ $7.5 \mathrm{~cm}$ ) に入れ，クン蒸 
ガスの浸透状態を知るためのものには, ダイズ, 小麦 粉, コーンスターチ各 $2 \mathrm{~kg}$ ，玄米にあっては $3 \mathrm{~kg}$ を書 類封筒に入れたものの中心部に入れ, 対応試料として浸 透を加味しないものは, 単に試料をクン蒸容器内の空間 に置いて薬効を調べた。

また，種子類の発芽に及ぼす影響を知るための試料と しては, 泉州平型タマネギ $(1 \mathrm{~g})$, パンジー（市販のもの 1 袋)，コマツナ $(1 \mathrm{~g})$ 和よび緑豆 $(200 \mathrm{~g})$ を沶の拉の小 封筒に入れて用いた。

クン蒸容器には $1.5 \mathrm{~m}^{3}$ の金属製クン蒸容器（温度調 節器・扇風機付）を用い，さきに記した幾つかの当該供 試試料をこれの中央部に入れ，25 28 0 のとで実験を 行なった. 投薬に際しては, 薬量が増すほどクン蒸容器 内が加圧状態になるため, 下部より流入する供試薬剂 （カポックス10)の気化ガスが，ある程度上部に達するま で上部の小センを開いて扣き，クン蒸容器内の空気との 置換を多少なりともはかった，このよらにして所定の薬 量を投入したのち, 扇風機を回して容器内のガス濃度を 均一化した. クン蒸容器内に和将る有効成分の酸化エチ レン濃度は北川式検知管を用いて 測定し記 録にとどめ た.

クン蒸後に和ける系状菌関係の試料は, 所定菌の加害 玄米粒をクン蒸の対象としているため, これを寒天培地 上に並べて至適繁殖条件におき, 生育の有無を 2 週間に わたって観察した. また, 種子類の発芽試験は, 隇菌水
で洗浄後，あらかじめ殺菌を施した脱脂綿入の大形シャ ーレに滅菌水を注いで適度の湿り気を与えたものの上に 各 100 粒ずつ入れ, $28 \sim 30^{\circ}$ のもとに和いて発芽の状態 を観察する方法によった。

\section{実験結果および考察}

クン蒸時間および投薬量を異にした際の試料の殺菌状 態は第 1 表のごとくであり, 既報24)6)のように供試菌種 間に抵抗差を認めている。 また, 物質間に括けるクン蒸 ガスの浸透差は, 本実験の場合には量の少ないこともあ り判然としないが，物質によって浸透状態の異なること はすでに立証2)416)されている.

さて,このよらな現象はとにかくとして, 殺菌効果 は, $250 \mathrm{~g} / 1.5 \mathrm{~m}^{3}, 48$ 時間と $200 \mathrm{~g} / 1.5 \mathrm{~m}^{3}, 72$ 時間の線で 目的を達成していることがわかる，しかしながら，ここ で留意すべきは，この基礎実験における有効成分の酸化 エチンン濃度（庫内濃度 $0.8 \%$ を示す $27 \sim 28^{\circ}$ のもとて 48 時間，また $0.7 \%$ を示す $25 \sim 27^{\circ}$ のもとであれば 72 時間のクン蒸条件) は，実用の際にも応用できるが，投 薬量の值そのものを直ちに一般に行なら保管豰類のクン 蒸条件として適用できない。なぜならば，実用の場合に は保管物質量と関連した吸着量の増加，あるいはガスの 脱漏等が考慮されるからである，それゆえこれらの点に ついては，さらに規模を大きくした条件で実験を行な い, 投薬量の実用値を究明したいと思っている.

つぎに，クン蒸ガスが種子の発芽能力に及洔す影響に

第 1 表「カポックス 10」の殺菌効果

\begin{tabular}{|c|c|c|c|c|c|c|c|c|c|c|c|c|c|}
\hline \multirow{2}{*}{$\begin{array}{c}\text { 「カポックス } \\
10 」 \text { 投薬量 } \\
\left(\mathrm{g} / 1.5 \mathrm{~m}^{3}\right)\end{array}$} & \multirow{2}{*}{$\begin{array}{l}\text { 酸化エ } \\
\text { チ レン } \\
\text { 濃 }(\%) \\
(\%)\end{array}$} & \multirow{2}{*}{$\begin{array}{l}\text { クン } \\
\text { 蒸時 } \\
\text { 間 }\end{array}$} & \multirow{2}{*}{$\begin{array}{l}\text { クン蒸温 } \\
\text { 度 }\left({ }^{\circ} \mathrm{C}\right)\end{array}$} & \multicolumn{5}{|c|}{ 米粒寄生の Pen. islandicum } & \multicolumn{5}{|c|}{ 米粒寄生の Asp. cheralieri } \\
\hline & & & & $\begin{array}{r}\text { ダイズ } \\
\text { 内 }\end{array}$ & 玄米内 & $\begin{array}{r}\text { 小麦粉 } \\
\text { 内 }\end{array}$ & $\begin{array}{l}\text { コーンス } \\
\text { ターチ内 }\end{array}$ & $\begin{array}{l}\text { 容器内 } \\
\text { の空間 } \\
\end{array}$ & $\begin{array}{r}\text { ダイズ } \\
\text { 内 }\end{array}$ & 玄米内 & $\begin{array}{r}\text { 小麦粉 } \\
\text { 内 }\end{array}$ & $\begin{array}{l}コ ー ン ス ~ \\
\text { ターチ内 }\end{array}$ & $\begin{array}{l}\text { 容器内 } \\
\text { の空間 } \\
\end{array}$ \\
\hline 50 & 0.18 & 24 & 25 & ++ & ++ & ++ & + & ++ & ++ & ++ & ++ & + & ++ \\
\hline 150 & 0.4 & 24 & 26 & ++ & ++ & ++ & + & ++ & ++ & ++ & ++ & + & ++ \\
\hline 250 & 0.8 & 24 & $25 \sim 26$ & ++ & ++ & ++ & + & ++ & ++ & ++ & ++ & + & ++ \\
\hline 250 & 0.8 & 24 & 28 & & $-\quad-$ & $-\quad-$ & & $-\quad-$ & & $+\quad+$ & ++ & & ++ \\
\hline 250 & 0.8 & 24 & $27 \sim 28$ & - & $-\quad-$ & $-\quad-$ & - & -- & ++ & ++ & ++ & + & + \\
\hline 300 & 1.15 & 24 & $26 \sim 27$ & -- & -- & $-\quad-$ & - & -- & ++ & ++ & ++ & + & ++ \\
\hline 500 & 1.3 & 24 & $26 \sim 27$ & - & $-\quad-$ & -- & - & $-\quad-$ & ++ & $+\quad+$ & ++ & + & ++ \\
\hline *1500以上 & & 24 & & & I & $-\quad-$ & & $-\quad-$ & & I & -- & & -- \\
\hline 150 & 0.6 & 48 & 25 & -- & $-\quad-$ & $-\quad-$ & - & -- & ++ & ++ & ++ & + & ++ \\
\hline 200 & 0.8 & 48 & $27 \sim 28$ & -- & $-\quad-$ & -- & - & -- & ++ & ++ & + & + & + \\
\hline 250 & 0.75 & 48 & $25 \sim 26$ & $-\quad-$ & -- & $-\quad-$ & - & - & ++ & ++ & + & + & ++ \\
\hline 250 & 0.8 & 48 & $27 \sim 28$ & $-\quad-$ & -- & $-\quad-$ & - & $-\quad-$ & $-\quad-$ & $-\quad-$ & -- & - & -- \\
\hline 150 & 0.45 & 72 & $20 \sim 22$ & -+ & ++ & ++ & + & $-\quad-$ & ++ & ++ & ++ & + & ++ \\
\hline 200 & 0.7 & 72 & $25 \sim 27$ & -- & -- & -- & - & -- & -- & -- & -- & - & -- \\
\hline
\end{tabular}

* 第 6 報 6$)$ 第 2 表より拔萃 ただし，投薬量に対する濃度の理論值はつぎのごとくである.

$50 \mathrm{~g} / 1.5 \mathrm{~m}^{3} \sim 0.17 \%$

$250 \mathrm{~g} / 1.5 \mathrm{~m}^{3} \sim 0.84 \%$
$150 \mathrm{~g} / 1.5 \mathrm{~m}^{3} \sim 0.51 \%$

$300 \mathrm{~g} / 1.5 \mathrm{~m}^{3} \sim 1.01 \%$
$200 \mathrm{~g} / 1.5 \mathrm{~m}^{3} \sim 0.67 \%$

$500 \mathrm{~g} / 1.5 \mathrm{~m}^{3} \sim 1.68 \%$ 

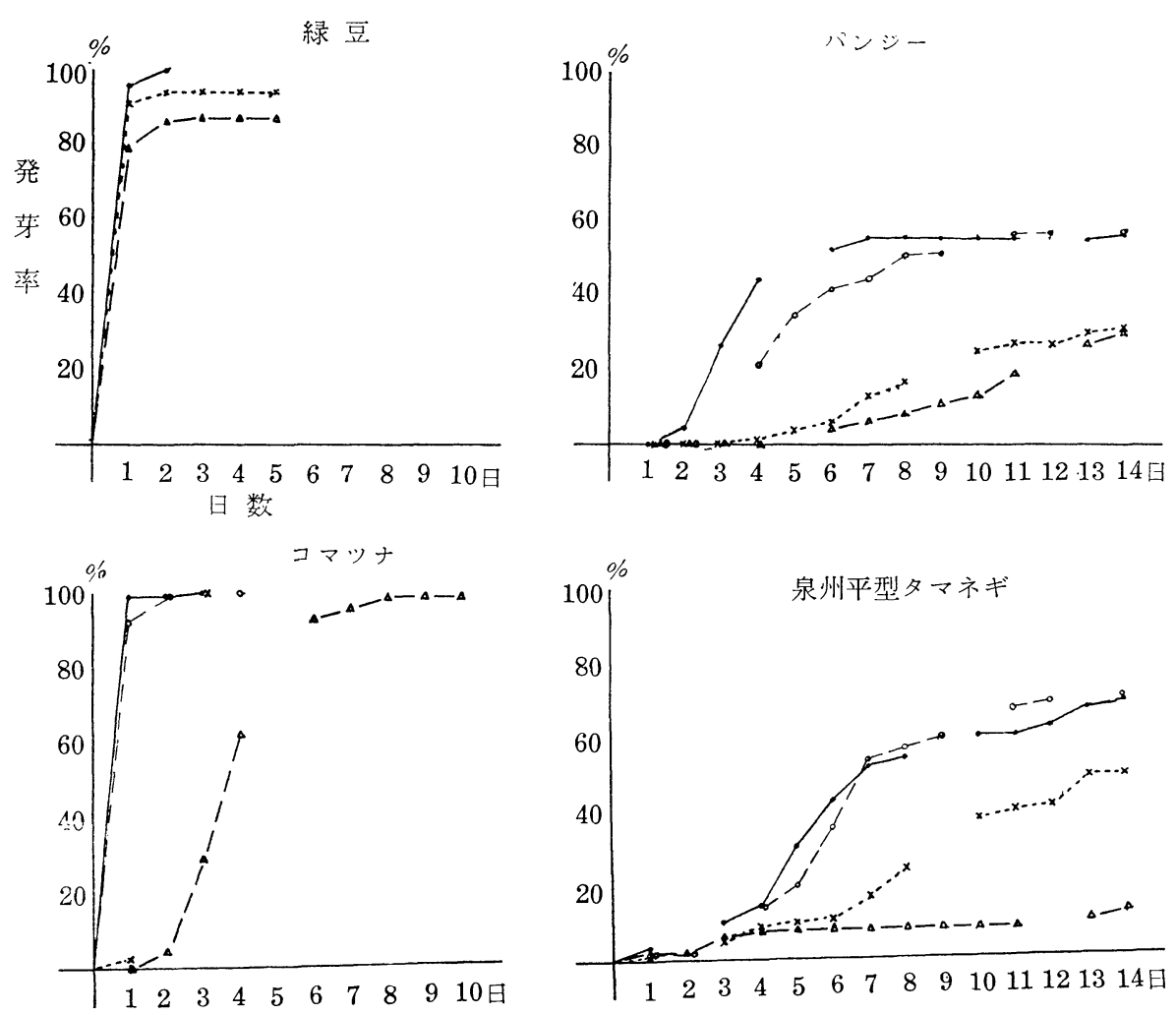

第 1 図「カポックス10」が発芽に及ぼす影響

- - 䒜クン湴

$\triangle$ 一 $\triangle 200 \mathrm{~g} / 1.5 \mathrm{~m}^{3}, 25 \sim 27^{\circ}$ のもとで 72 時閒クン蒸したもの

$\times \cdots \times 250 \mathrm{~g} / 1.5 \mathrm{~m}^{3}, 27 \sim 28^{\circ}$ のもとで 48 時間クン蒸したもの

○- -○ $300 \mathrm{~g} / 1.5 \mathrm{~m}^{3}, 25^{\circ}$ のもとで 24 時間クン蒸したもの

ついてであるが，これも同一容積内に同量の薬剤を投入 しても，物質量の多少によって差があるとされているの で，本実験の場合には，試料も少ないことから最悪の条 件下といらことになる。 そこで，ここでも投薬量でな く, クン蒸容器内の酸化エチレンの濃度值で理解するの が妥当と考える。

種子の発芽に閔しては，さきに殺菌効果を㢹められた 2 区分に $300 \mathrm{~g} / 1.5 \mathrm{~m}^{3}, 24$ 時間クン蒸のものを加え掲載 すれ代，第 1 図のごとくである。これより推察すると， 投薬量の増大よりもクン蒸時間の長期にわたる方が，発 芽への影響の大きい傾向がらかがえる.

この発芽試験の結果はクン蒸終了直後に調べたもので あるが，クン蒸したのち，日数が経過するにしたがって 発芽率が低下していく様相を認めたので, これを中心に つぎの計画を試み，これらの点を究明した。

\section{B）特殊容器を用い，クン蒸ガスを置換した場合}

一般クン蒸方法によった場合における系状菌の死隇状 態と，その効果を示した時点での種子類に及ぼす影響な どについて幾つかの知見を得た。しかし，とくに種子の
発芽関係で残された，クン蒸時間の違いによる影響差， あるいはクン蒸後にお忊る経過数との関係など未知の 点があるので, 殺菌効果の検討も含めて酸化エチレンの 濃度を高めた条件での実験を武みた。

\section{実験方法}

各区分の実験ごとに用いた種子類は，ダイズ（キタミ

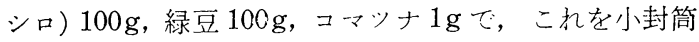
に入れて供試した。系状菌への效果を知る陚料としては 前項の場合之同様, Pen. islandicum, Asp. chevalieri を玄米に寄生させたものを両端綿センのガラス管内に入 れ, クン蒸容器内の空間と書類封筒内の緑豆 $2 \mathrm{~kg}$ の中 心部とに入れて供試した。

クン蒸剂には, 主成分の酸化ェチレン 30 に対し炭酸ガ ス70の割合の混合体（カポックス30）を用い, クン蒸容 器は, 投薬に際して, クン蒸容器内を脱気してクン蒸ガ スと置換することが可能な $41 \mathrm{~L}$ 容量の小型カポックス用 隇菌器 ${ }^{6}$ を使用した。この場合のクン蒸は $25^{\circ}$ のもとで 行なった.

効果の判定は, 発芽試験をクン蒸直後と一定日時を経 
過したものについても行なった以外，いずれも前項と同 様の方法によった。

\section{実験結果および考察}

クン蒸容器内の酸化エチレン濃度 $30 \%, 25^{\circ}$ のもとで, 所定時間のクン蒸を行なった際の殺菌効果は, 第 2 表の ごとく短時間で得られており，この様相は前報6)の結果 とほぼ類似している。

第 2 表 酸化エチレン $30 \%+$ 炭酸ガス $70 \%$ 25 もとで各時間クン蒸を行なった際の殺菌効果

\begin{tabular}{|c|c|c|c|c|}
\hline \multirow[b]{2}{*}{$\begin{array}{l}\text { クン蒸 } \\
\text { 時間 }\end{array}$} & \multicolumn{2}{|c|}{$\begin{array}{c}\text { 米粒寄生の } \\
\text { Pen. islandicum }\end{array}$} & \multicolumn{2}{|c|}{$\begin{array}{c}\text { 米粒寄生の } \\
\text { Asp. cheralieri }\end{array}$} \\
\hline & 緑豆内 & 外 & 緑豆内 & 外 \\
\hline 30 分 & ++ & ++ & ++ & ++ \\
\hline 1 時間 & $-\quad-$ & - & ++ & ++ \\
\hline 2 時間 & $-\quad-$ & -- & -- & -- \\
\hline 3 時間 & -- & -- & - & $-\quad-$ \\
\hline 6 時間 & - & - & - & -- \\
\hline 20 時間 & $-\quad-$ & - & -- & -- \\
\hline
\end{tabular}

供試した種子の発芽状態については, クン蒸直後と一 定日数を経過したのちに播種してそれぞれの様相を調べ て第 2 図を得た。これより明らかなように, 緑豆では, クン蒸時間の長短あるいはクン蒸後に扣ける保管日数が 経過しても発芽には汇とんど影響を受けていないことが わかる、コマツナでは, クン蒸直後の場合に利いて, ク ン蒸時間が長くなると, 最終の発芽率の值は無クン蒸区 のものとほとんど変らないが, 発芽するために日数を要 する傾向が認められる. また，クン蒸時間が長い区分ほ ぞ, クン蒸後の保管日数が経過するにしたがって, 発芽 に要する日数が長くなるとともに発芽率乞のものも低下 する傾向を示している.このような状態は, ダイズの場 合にも認められている.

\section{総括}

種子の発芽に及ぼすクン蒸剤の影響については, クン 蒸の目的である殺菌効果と関連して考えなくてはならな い.なぜならば, 殺菌効果を期待でき, かつ発芽を阻害 しない投薬量とクン蒸時間の組合わせを知ることが，実 用価值とつながるからである。このよらな観点より, 款
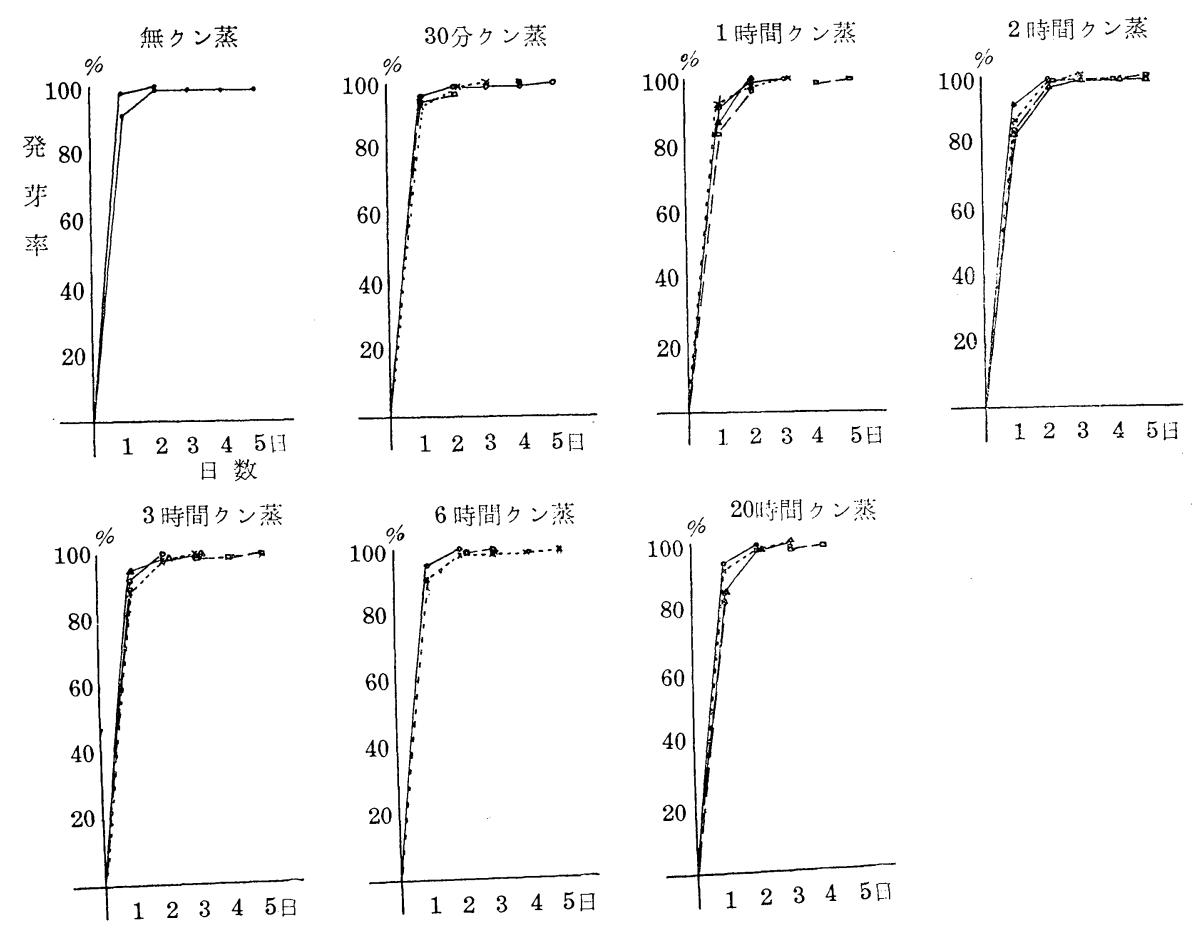

第 2 図 1 緑豆を酸化エチレン $30 \%+$ 炭酸ガス $70 \%, 25$ のもとで各時閒クン蒸を行なった 際の発芽状態

$\bigcirc-\bigcirc \quad$ クン蒸直後に打ける発芽状態
$\times \cdots \times \quad$ クン蒸後 3 日放置したものの発芽状態
$\square-\square \quad$ クン蒸後 10 日放置したものの発芽状態
$\Delta-\triangle \quad$ クン蒸後 14 日放置したものの発芽状態 


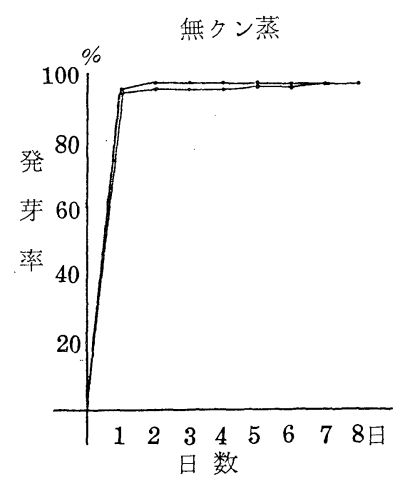

30 分クン蒸

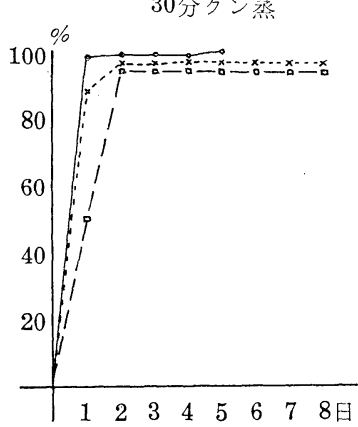

1 時間クン蒸
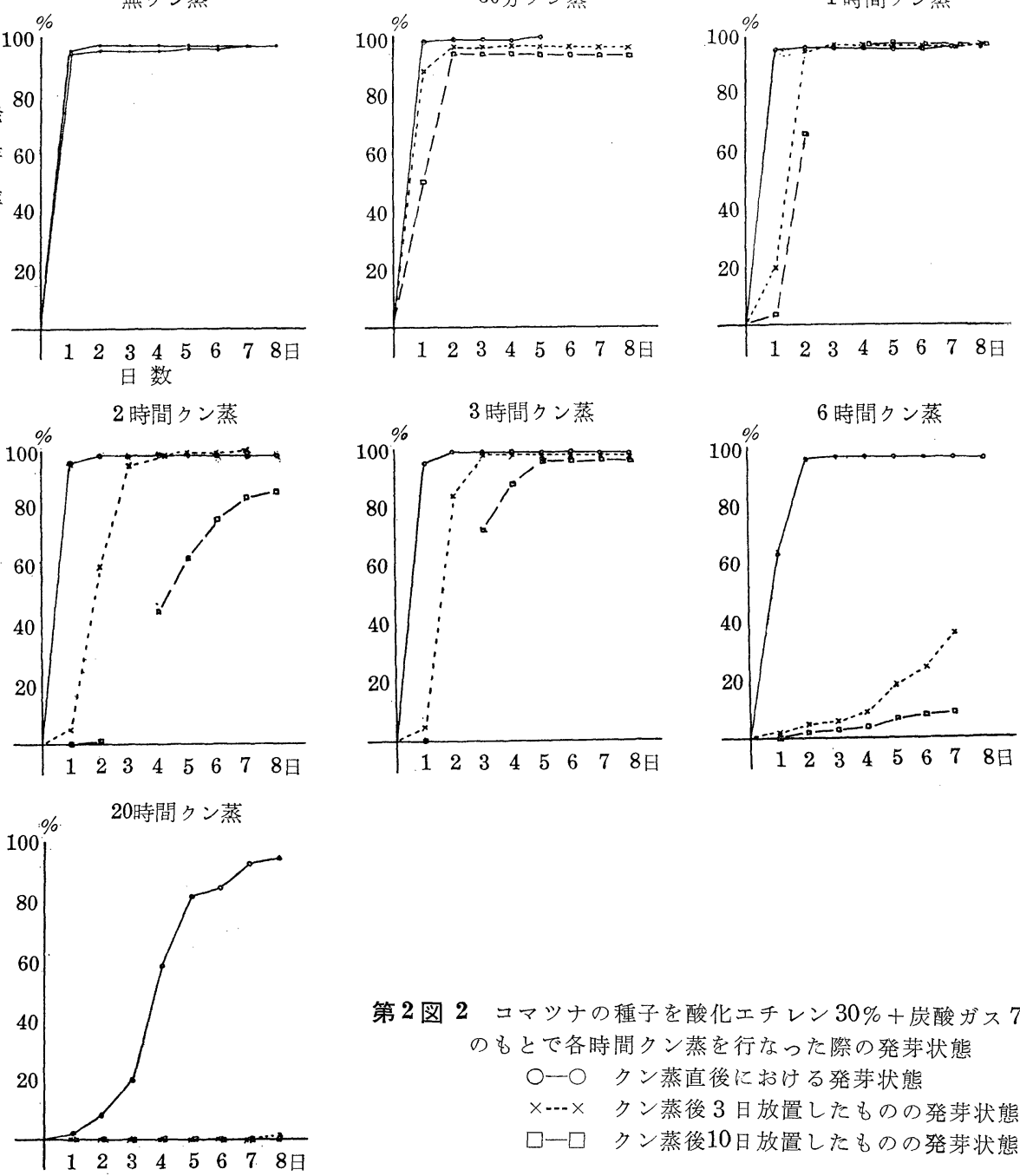

第 2 図 2 コマツナの種子を酸化エチレン $30 \%+$ 炭酸ガス $70 \%, 25^{\circ}$ のもとで各時間クン蒸を行なった際の発芽状態
○一○クン蒸直後における発芽状態
$\times-\cdots \times$ クン蒸後 3 日放置したものの発芽状態
$\square$ - クン蒸後10日放置したものの発芽状態
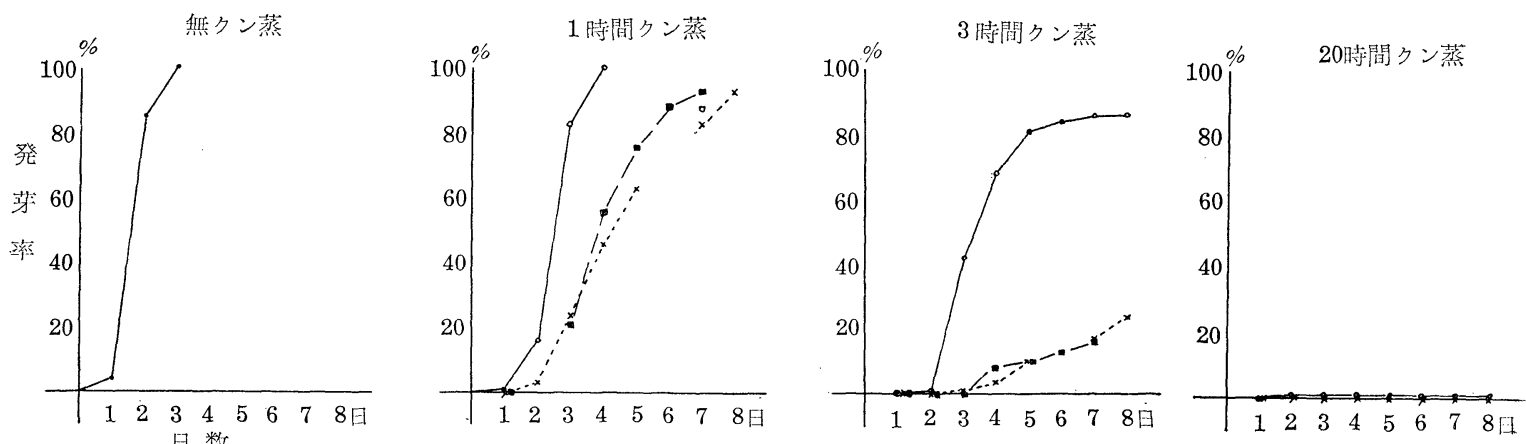

第 2 図 3 ダイズを酸化エチレン $30 \%$ +炭酸ガス $70 \%, 25^{\circ}$ のもとで各時間クン蒸を行なっ た際の発芽状態

○一○ クン蒸直後における発芽状態

$\times \cdots \times$ クン蒸後 3 日放置したものの発芽状態

- クン蒸後 7 日放置したものの発芽状態 
物の保管を阻害する要因として働く糸状菌の致死条件を 見いだすとともに，これと関連して種子類の発芽に及ぼ す影響を察知することを目途とし，一般クン蒸の方法と 特定容器内でクン蒸ガスを置換した場合とについて実験 を行ない，つぎのごとき知見を得た。

一般のクン蒸は, 酸化エチレン 10 と炭酸ガス 90 の混 合体を使用するのが一般的であるが，これによった場 合, 系状菌を殺菌しらる最低条件としてクン蒸容器内の 酸化エチレン濃度を $0.7 \%$ に保った場合には72時間，酸 化エチレン濃度 $0.8 \%$ の場合には48時間を要することを 知った.このいずれを採用するかについては，保管物質 への浸透状態なども考慮して定めるべきであるが，発芽 の点からすれば，濃度が高くともクン蒸時間の短かい方 が好ましい結果を得ている.なお，クン蒸容器内の酸化 エチレン濃度を $0.7 \%$ に保つには $200 \mathrm{~g} / 1.5 \mathrm{~m}^{3}, 0.8 \%$ の 場合には $250 \mathrm{~g} / 1.5 \mathrm{~m}^{3}$ の投薬量で理論的に算出される.

しかし，本実験のように供試料の少ない場合は問題はな いが，さきにも触れたようにクン蒸物質が増加するにつ れて吸着量も増すので, 必然的に投薬量も計算值より増 加しなければならないことを付記しておく.

また，酸化ェチレン30と炭酸ガス70の混合体を用い， クン蒸ガス置換法によってクン蒸容器内の酸化エチレン

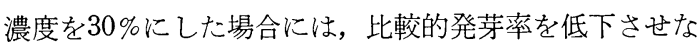
い2 時間といら短時間内において糸状菌を殺菌しうるの
で保管の種子類への利用も考えられる. しかし発芽に関 しては，種類によってクン蒸ガスの影響を受ける度合の 異なることを指摘したにとどめ，詳細についてはさらに 多種類のものを対象に実験を行ない, 報告を重ねたいと 思っている.

なお，穀類の保管を阻害する要因としての詝穀害虫に ついて，既報2416)のごとく糸状菌の致死条件よりも下 限で十分に効果が期待できるため,ここでは実験を省略 している.

稿を終るにあたり，実験に際して特殊器具，クン蒸剂 などの配慮を得た液化炭酸株式会社に謝意を表します。

\section{文献}

1) 戸部敬战, 原田豊秋, 太田輝夫, 鶴田 理：食衛 誌. 4, 130 (1963).

2) 鶴田理, 太田媈夫, 戸部敬哉, 原田豊秋: 同上. 4, 209 (1963).

3）小柳妙子, 鶴田 理, 太田輝夫：同上. 4, 214 (1963).

4) 鶴田 理, 太田輝夫, 戸部敬哉, 原田豊秋：同上. 5, 139 (1964).

5) 小柳妙子, 鶴田 理, 太田輝夫, 原田豊秋：同上. 5, 144 (1964).

6) 鶴田 理, 太田輝夫, 原田豊秋：同上. 6, 258 (1965). 